\title{
Accuracy of Digital Radiography and Cone Beam Computed Tomography on Periapical Radiolucency Detection in Endodontically Treated Teeth
}

\author{
Tadas Venskutonis ${ }^{1}$, Povilas Daugela ${ }^{2}$, Marijus Strazdas², Gintaras Juodzbalys² \\ ${ }^{1}$ Department of Oral Diseases, Lithuanian University of Health Sciences, Kaunas, Lithuania. \\ ${ }^{2}$ Department of Maxillofacial Surgery, Lithuanian University of Health Sciences, Kaunas, Lithuania.
}

\author{
Corresponding Author: \\ Tadas Venskutonis \\ Sauletekio g. 20 \\ LT-54350, Domeikava \\ Lithuania \\ Phone: +37061209694 \\ E-mail: tadasvens@gmail.com
}

\begin{abstract}
Objectives: The aim of the present study was to compare the accuracy of intraoral digital periapical radiography and cone beam computed tomography in the detection of periapical radiolucencies in endodontically treated teeth.

Material and Methods: Radiographic images (cone beam computed tomography [CBCT] scans and digital periapical radiography [PR] images) from 60 patients, achieved from September 2008 to July 2013, were retrieved from databases of the Department of Oral Diseases, Lithuanian University of Health Sciences. Twenty patients met inclusion criteria and were selected for further evaluation.

Results: In 20 patients (42.4 [SD 12.1] years, 65\% men and 35\% women) a total of 35 endodontically treated teeth (1.75 [SD $0.91] ; 27$ in maxilla and 8 in mandible) were evaluated. Overall, it was observed a statistical significant difference between the number of periapical lesions observed in the CBCT $(n=42)$ and radiographic $(n=24)$ examinations $(P<0.05)$. In molar teeth, CBCT identify a significantly higher amount of periapical lesions than with the radiographic method $(\mathrm{P}<0.05)$. There were significant differences between $\mathrm{CBCT}$ and $\mathrm{PR}$ in the mean number of lesions identified per tooth $(1.2 \mathrm{vs} 0.66, \mathrm{P}=0.03)$, number of teeth with lesions $(0.71$ vs $0.46, \mathrm{P}=0.03)$ and number of lesions identified per canal $(0.57$ vs $0.33, \mathrm{P}=0.005)$. Considering CBCT as "gold standard" in lesion detection with the sensitivity, specificity and accuracy considering as score 1 , then the same parameters of PR were $0.57,1$ and 0.76 respectively.

Conclusions: Within the limitations of the present study, it can be concluded that cone beam computed tomography scans were more accurate compared to digital periapical radiographs for detecting periapical radiolucencies in endodontically treated teeth. The difference was more pronounced in molar teeth.
\end{abstract}

Keywords: cone-beam computed tomography; dental radiography; endodontics; periapical periodontitis; root canal therapy; $\mathrm{X}$-ray diagnosis.

\footnotetext{
Accepted for publication: 15 May 2014

To cite this article:

Venskutonis T, Daugela P, Strazdas M, Juodzbalys G. Accuracy of Digital Radiography and Cone Beam Computed Tomography on Periapical Radiolucency Detection in Endodontically Treated Teeth.

J Oral Maxillofac Res 2014;5(2):e1

URL: http://www.ejomr.org/JOMR/archives/2014/2/e1/v5n2e1ht.pdf

doi: $10.5037 /$ jomr.2014.5201
} 


\section{INTRODUCTION}

Apical periodontitis (AP) is a chronic inflammatory disorder of periradicular tissues caused by aetiological agents of endodontic origin [1]. Whereas existing AP may influence the outcome of root canal treatment, its detection and characterisation represents an important pre-operative prognostic factor $[\underline{2}, \underline{3}]$. Advanced stage AP is characterized by inflammation and changes of periapical bone structure, resulting in resorption identified as radiolucencies in radiographs [4].

Intraoral periapical radiographs (PR) have been used for many years to detect AP [5]. However, it was shown that periapical lesions may only become visible on radiographs when periapical radiolucency is reaching nearly $30 \%-50 \%$ of mineral bone loss [6]. Furthermore, surrounding bone density, X-ray angulations and contrast [7], tooth location [8] and the three- dimensional shape of the lesion [9] can affect radiographic detection of periapical lesions. When lesions are confined within the cancellous bone or covered by a thick cortex, AP could be radiographically undetectable because the overlying cortical plate may mask the periapical lesion $[10,11]$. Intraoral PR images have inherent limitations owing to their two-dimensional view of threedimensional structures, which somewhat restricts the information regarding size, extension, and location of periapical lesions [12]. The lack of three-dimensional information and masking of areas of interest by overlying anatomy (anatomic noise) are of particular relevance in endodontics.

Nowadays, cone beam computed tomography (CBCT) has been considered as a gold standard for diagnostic procedures in endodontics [13]. Early CBCT scanners for dental use were developed by Mozzo et al. [14] and Arai et al. [15] in the late 1990s. Recently, CBCT has been used to improve the observation of bone structures and their relationship with adjacent anatomical structures in three dimensions [16]. Compared with radiographic images, $\mathrm{CBCT}$ has the potential to provide more accurate information regarding the presence of AP [17-19]. Taking into account that CBCT has a better accuracy than PR, it is likely to find more cases of AP with the former than to conventional radiographic systems [3]

Cheung et al. [19] showed that molar teeth are the most problematic in terms of radiographic interpretation of the presence of AP when using PR, because $63 \%$ increase in the amount of periapical lesions detection was observed using CBCT. Hence, the prevalence of AP might be underestimated with conventional radiographic analysis.
The aim of the present study was to compare the accuracy of intraoral periapical radiography and cone beam computed tomography in the detection of periapical radiolucencies of endodontically treated teeth.

\section{MATERIAL AND METHODS Patient selection}

This study was approved by the Local Ethics Committee of Kaunas, Lithuania. Radiographic images (CBCT scans and digital PR images) from 60 patients, achieved from September 2008 to July 2013, were retrieved from databases of the Department of Oral Diseases, Lithuanian University of Health Sciences. For PR examination, the paralleling technique was used in two directions in the horizontal plane (mesial and distal angulation) at $70 \mathrm{kV}$ and $4 \mathrm{~mA}$ using a digital radiographic system (Kodak RVG 6100; Carestream Health, Rochester, NY, USA). Exposure time varied according to the tooth's group $(0.11-0.19 \mathrm{~s})$. CBCT scans were performed with i-CAT scanner (Imaging Sciences International Inc., Hatfield, PA; $120 \mathrm{kVp}, 3-8 \mathrm{~mA}, 0.2 \mathrm{~mm}$ voxel resolution, $6 \times 16 \mathrm{~cm}$ field of view, $26.9 \mathrm{~s}$ acquisition time). Patients were selected according to the following inclusion criteria: 1) two digital radiological diagnostic methods (CBCT and PR) carried out within a period of one month; 2) the quality of radiographic images sufficient for the assessment of the periapical status of the teeth; 3) at least one endodontically treated tooth present at the first radiographic exam. Twenty patients met these criteria and were selected for further evaluation.

\section{Radiographic evaluation}

CBCT and digital PR images were analysed with i-CAT viewing software (Imaging Sciences International, Inc., Hatfield, PA, USA) and Kodak dental imaging software version 6.12.11.0 (Carestream Dental LLC, Atlanta, GA, USA), respectively. CBCT images were analysed in the sagittal, coronal, and axial planes. The filters were set to normal, and only brightness and contrast were adjusted. Images were analysed on a 27 -inch flat panel display screen with a pixel resolution of 2,560 x 1,440 in a dimly lit room without time restrictions.

A periapical lesion was defined as a radiolucency located in the periapical area of the tooth in connection with the apical part of the root exceeding at least twice the width of the periodontal ligament space [20]. For CBCT images, the same criterion 
Table 1. Number of periapical lesion detected in CBCT and periapical examination (sensitivity, specificity, positive predictive value [PPV], negative predictive value [NPV], accuracy).

\begin{tabular}{|c|c|c|c|c|c|c|c|}
\hline \multirow{2}{*}{ Method } & \multicolumn{2}{|c|}{ Periapical lesion } & \multirow{2}{*}{$\begin{array}{c}\text { Sensitivity } \\
(\%)\end{array}$} & \multirow{2}{*}{$\begin{array}{c}\text { Specificity } \\
(\%)\end{array}$} & \multirow{2}{*}{$\begin{array}{l}\text { PPV } \\
(\%)\end{array}$} & \multirow{2}{*}{$\begin{array}{l}\text { NPV } \\
(\%)\end{array}$} & \multirow{2}{*}{ Accuracy } \\
\hline & Presence & Absence & & & & & \\
\hline PR & 24 & 50 & 57.1 & 100 & 100 & 64 & 0.76 \\
\hline CBCT & 42 & 32 & 100 & 100 & 100 & 100 & 1 \\
\hline
\end{tabular}

was applied, and the radiolucency had to be visible at least in two image planes.

The datasets were collected by one investigator (endodontist) who did not participate on the evaluation of the images. Two previously calibrated examiners (both endodontists) scored each image separately for the assessment of the presence of periapical radiolucencies. Several parameters were evaluated: (i) number of root canals per tooth, (ii) numbers of lesion per tooth, (iii) number of teeth with lesions, (iv) number of lesions per canal. The periapical status was scored as 0 and 1 meaning absence and presence of lesion, respectively. The observers were blinded to the patients' data. The examiners firstly assessed the PR and then the CBCT images and results were compared. In case of disagreement, the case was discussed and a consensus was reached. The overall kappa index for inter-observers agreement was calculated by using weighted kappa. Intra-observers agreement was not examined due to the high kappa values reported in previous investigations $[\underline{13}, \underline{16}, \underline{21}]$.

\section{Statistical analysis}

Statistical analysis was performed with SPSS version 19.0 (SPSS, Inc., Chicago, IL, USA). Parametric data were expressed as mean and standard deviation (M [SD]). Two independent groups of quantitative variables for comparison applies to parametric Student's t-test and nonparametric Mann-Whitney test, while for more than two groups parametric analysis of variance ANOVA and nonparametric tests were used. A chi-square test was used to compare the accuracy of PR and CBCT in diagnosis of periapical lesions. Sensitivity, specificity, positive and negative predictive values were calculated on the overall number of detected lesions. Kappa values $\leq 0.2$ were considered poor; 0.21 - 0.4 fair; 0.41 - 0.6 moderate; $0.61-0.8$ good and 0.81- 1 very good agreement [22] Significance was set at P-value of 0.05.

\section{RESULTS}

In 20 patients $(42.4$ [12.1] years, $65 \%$ men and $35 \%$ women) a total of 35 endodontically treated teeth
Table 2. PR and CBCT assessment of the endodontically treated teeth

\begin{tabular}{l|c|c|c}
\hline & $\begin{array}{c}\text { Periapical } \\
\text { Mean (SD) }\end{array}$ & $\begin{array}{c}\text { CBCT } \\
\text { Mean (SD) }\end{array}$ & P \\
\hline All teeth (n= 35) & & & \\
\hline Number of canals & $1.94(1.08)$ & $2.11(1.26)$ & N.s. \\
\hline Number of lesions per tooth & $0.66(0.87)$ & $1.2(1.18)$ & $0.03^{\mathrm{a}}$ \\
\hline Number of teeth with lesion & $0.46(0.5)$ & $0.71(0.46)$ & $0.03^{\mathrm{a}}$ \\
\hline Number of lesions per canal & $0.33(0.48)$ & $0.57(0.5)$ & $0.005^{\mathrm{a}}$ \\
\hline Anterior teeth (n=11) & & & \\
\hline Number of canals & $1(0)$ & $1(0)$ & N.s. \\
\hline Number of lesions per tooth & $0.73(0.47)$ & $0.91(0.3)$ & N.s. \\
\hline Number of teeth with lesion & $0.73(0.47)$ & $0.91(0.3)$ & N.s. \\
\hline Number of lesions per canal & $0.73(0.47)$ & $0.91(0.3)$ & N.s. \\
\hline Premolars teeth (n= 11) & & & \\
\hline Number of canals & $1.36(0.5)$ & $1.45(0.52)$ & N.s. \\
\hline Number of lesions per tooth & $0.27(0.47)$ & $0.55(0.52)$ & N.s. \\
\hline Number of teeth with lesion & $0.27(0.47)$ & $0.55(0.52)$ & N.s. \\
\hline Number of lesions per canal & $0.20(0.41)$ & $0.38(0.5)$ & N.s. \\
\hline Molars teeth (n = 13) & & & \\
\hline Number of canals & $3.23(0.44)$ & $3.62(0.51)$ & $0.049^{\mathrm{a}}$ \\
\hline Number of lesions per tooth & $0.92(1.26)$ & $2(1.58)$ & N.s. \\
\hline Number of teeth with lesion & $0.38(0.51)$ & $0.69(0.48)$ & N.s. \\
\hline Number of lesions per canal & $0.28(0.45)$ & $0.55(0.5)$ & $0.008^{\mathrm{a}}$ \\
\hline
\end{tabular}

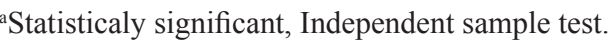

$\mathrm{SD}=$ standard deviation; $\mathrm{n}=$ number of teeth; N.s. = non-significant .

(1.75 [0.91]; 27 in maxilla and 8 in mandible) were evaluated. The distribution of the teeth (11 anteriors, 11 premolars and 13 molars) was equal $(\mathrm{P}>0.05)$. The calculated power of the sample was 0.86 . The kappa indexes for inter-observer agreement were 0.82 and 0.86 for PR and CBCT images, respectively.

Overall, it was observed a significant difference between the number of periapical lesions observed in $\operatorname{CBCT}(n=42)$ and radiographic $(n=24)$ examinations $(\mathrm{P}<0.05)$ (Table 1$)$. In molar teeth, CBCT identify a significantly higher amount of periapical lesions than with the radiographic method $(\mathrm{P}<0.05)$

Despite no significant difference in the mean number of canals was observed between CBCT and PR (2.11 [1.26] vs 1.94 [1.08], $\mathrm{P}>0.05)$, there were significant differences between $\mathrm{CBCT}$ and $\mathrm{PR}$ in the mean number of lesions per tooth (1.2 [1.18] vs 0.66 [0.87], $\mathrm{P}=0.03)$, number of teeth with lesions $(0.71[0.46] \mathrm{vs}$ $0.46[0.5], \mathrm{P}=0.03)$ and number of lesions per canal (0.57 [0.5] vs $0.33[0.48], \mathrm{P}=0.005)$ (Table 2$)$. 
No difference was found between methods within each group of teeth, except in molars in which CBCT identified a higher number of canals $(3.62[0.51] \mathrm{vs}$ 3.23 [0.44], $\mathrm{P}=0.049)$ and of lesions per canal $(0.55$ [0.5] vs 0.28 [0.45], $\mathrm{P}=0.008$ ).

In both methods the mean number of lesions per canal in anterior teeth was higher compared with premolar and molar teeth $(\mathrm{P}<0.03)$. In CBCT evaluation more lesions per tooth was found in molars than in the other groups of teeth $(\mathrm{P}=0.014)$.

Considering CBCT as "gold standard" in lesion detection with the sensitivity, specificity and accuracy considering as score 1, the same parameters of PR were $0.57,1$ and 0.76 respectively (Table 1 ).

\section{DISCUSSION}

Detection and characterisation of AP represents an important pre-operative prognostic factor for the root canal treatment [2,3]. Advanced stage AP and the evaluation of the endodontic treatment are easily identified with conventional radiographic methods such as intraoral PR. Though PR still remain as the best routinely employed method for the evaluation of the periapical status of teeth, diagnosis, and treatment planning, it has several limitations: such as the presence of anatomical noise, the two-dimensionality and geometric distortion [3, 16]. Gao et al. [9] mentioned that PR limitations are most expressed in the assessment of molar teeth. The apical region of maxillary molars is often overlapped with the image of the radiodense zygomatic process. Similarly, the cortical plate of the mandible can make the identification of small, developing lesion unpredictable [9] (Figure 1). It is interesting to know that even image enhancement did not increase diagnostic accuracy [23,24]. Furthermore, Barbat and Messer [24] observed a large inter-observer variation for both film and digital radiographs. Clinically, CBCT images provide more relevant information than periapical images and eliminate the superimposition of anatomical structures $[\underline{25}, \underline{26}]$, which is useful to identify pathological processes occurring within the cancellous bone [3] (Figure 2). It is established that during the evaluation of radiographic methods, the reference method is either post-mortem study or biopsy on surgical intervention [27]. In a study by Velvart et al. [12], all 78 CBCT-scanned human periapical lesions were confirmed to be true bone defects during periapical surgery. Otherwise, clinical documentation of the diagnostic accuracy of CBCT is lacking.

Taking into account the importance of the reliability of the method for detection of AP, the present study was performed to compare the accuracy of digital PR and CBCT scans in detecting of periapical radiolucencies in endodontically treated teeth. Results revealed very good inter-observers agreement for both PR and CBCT diagnostic methods. Overall there were identified 42 lesions by means of CBCT and 24 lesions using PR (57.1\% increase) (Table 1). This is in accordance with Cheung et al. [19], which reported $63 \%$ increase in the amount of periapical lesions detected with CBCT.

In present study, CBCT diagnostic method was superior in identifying root canals in molar teeth $(P=0.049)$. The number of periapical lesions for molars per tooth detected using PR was 0.92 (1.26)

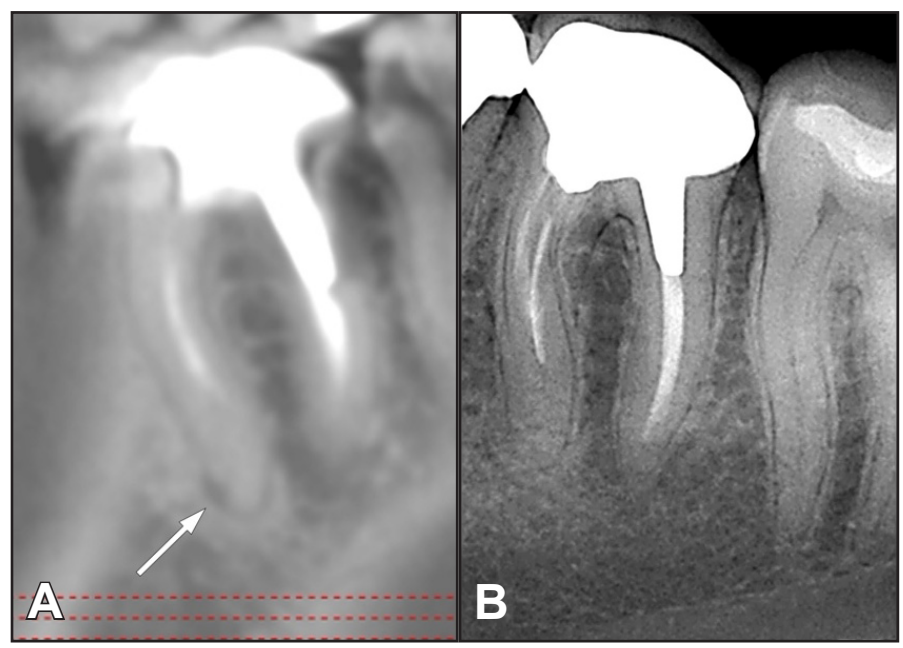

Figure 1. $A=C B C T$ image in a sagittal view showing the presence of periapical radiolucency on the apical aspect of the mesial root of a mandibular first molar. $\mathrm{B}=$ digital periapical radiography of the same tooth showing a normal aspect of the bone in the periapical area.

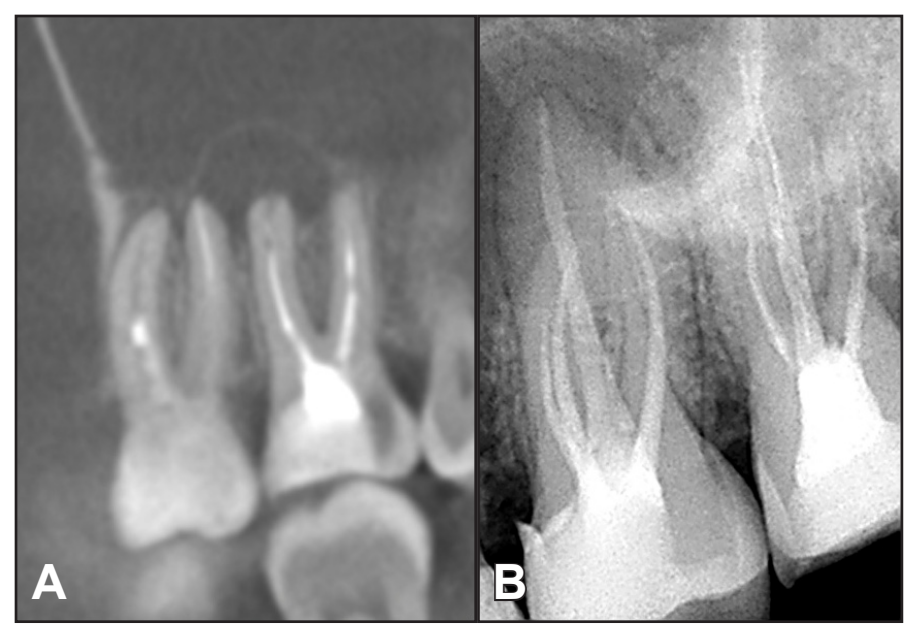

Figure 2. $A=$ CBCT image in a sagittal view showing the presence of huge periapical radiolucency on the periapical area of maxillary first and second molars. $\mathrm{B}=$ digital periapical radiography of the same teeth showing a normal aspect of the bone in the periapical area. 
versus 2 (1.58) with CBCT. This is in agreement with Cheung et al. [19] who observed 0.95 (1.08) and 1.55 (1.18) lesions in molars, detect by CBCT and $\mathrm{PR}$, respectively. In contrast, there was no difference between both examination methods related to the detection of periapical lesions in anterior and premolar teeth.

Existing AP may influence the outcome of root canal treatment [28], thus it is important to diagnose AP lesions using the best method available and our study showed that in molar teeth more than one lesion was observed per tooth $(2[1.58])$. This is in agreement with clinical studies that suggested that radiological findings obtained from CBCT may represent the "true" status of the periapical tissues $[\underline{16}, \underline{29}, \underline{30}]$. Even in a study that used histopathological findings as "gold standard", CBCT scans were more sensitive in detecting AP compared with orthopantomograms, which were more likely to miss AP when it was present [10].

Liang et al. [31] reported sensitivity, specificity, and accuracy values for CBCT were 1 and, for PR, 0.64, 1 , and 0.79 , respectively in artificially created lesions. Paula-Silva et al. [32] reported accuracy values for CBCT and PR of 0.92 and 0.78 , respectively, when histopathological findings were considered as gold standard, which is similar to our findings. Other in vitro studies have also showed the superiority of CBCT images over conventional radiography in diagnosing endodontic treatment complications such as vertical root fracture [33,34], root perforation [35] and resorption $[\underline{17}, \underline{36}]$.

The drawbacks of CBCT include cost, lack of clinical documentation of the diagnostic accuracy and a potentially higher radiation dose, depending on the equipment and the field of view (FOV) used [27]
Radiation dose of the CBCT machines must be kept as low as possible. In order to reduce radiation dosage with CBCT a smaller field of view less projections $\left(180^{\circ}\right)$ and a bigger voxel sizes could be used $[\underline{37}, \underline{38]}$. The major drawback of this study is that the true status of the periapical tissues was not be confirmed. Besides, PR exam was not performed by the same operator and even using the parallel technique, slight differences on the image might happen. Additionally, radiographic visible bone lesion is usually larger than that depicted by the radiological image; consequently, the extension of bone destruction is certainly important [39]. It is well known that taking radiographs in different projections increases the possibility of a correct diagnosis compared with a single radiograph [40].

\section{CONCLUSIONS}

Within the limitations of the present study, it can be concluded that cone beam computed tomography scans were more accurate compared to digital periapical radiographs for detecting periapical radiolucencies in endodontically treated teeth. The difference was more pronounced in molar teeth. Cone beam computed tomography can be introduced in to diagnostic procedures especially when dealing with the molar teeth.

\section{ACKNOWLEDGMENTS AND DISCLOSURE STATEMENTS}

The authors report no conflicts of interest related to this study.

\section{REFERENCES}

1. Nair PN. Pathogenesis of apical periodontitis and the causes of endodontic failures. Crit Rev Oral Biol Med. 2004 Nov 1;15(6):348-81. Review. [Medline: 15574679]

2. Ng YL, Mann V, Rahbaran S, Lewsey J, Gulabivala K. Outcome of primary root canal treatment: systematic review of the literature -- Part 2. Influence of clinical factors. Int Endod J. 2008 Jan;41(1):6-31. Epub 2007 Oct 10. Review. [Medline: 17931388]

3. Patel S, Wilson R, Dawood A, Foschi F, Mannocci F. The detection of periapical pathosis using digital periapical radiography and cone beam computed tomography - part 2: a 1-year post-treatment follow-up. Int Endod J. 2012 Aug;45(8):711-23. [Medline: 22775142] [doi: 10.1111/j.1365-2591.2012.02076.x]

4. Nair PN, Sjögren U, Figdor D, Sundqvist G. Persistent periapical radiolucencies of root-filled human teeth, failed endodontic treatments, and periapical scars. Oral Surg Oral Med Oral Pathol Oral Radiol Endod. 1999 May;87(5):61727. [Medline: 10348524] [doi: 10.1016/S1079-2104(99)70145-9]

5. Tyndall DA, Rathore S. Cone-beam CT diagnostic applications: caries, periodontal bone assessment, and endodontic applications. Dent Clin North Am. 2008 Oct;52(4):825-41, vii. Review. [Medline: 18805231] [doi: $10.1016 /$ j.cden.2008.05.002]

6. Bender IB, Seltzer S. Roentgenographic and direct observation of experimental lesions in bone. Part I. J American Dent Assoc. 1961 Feb 62;152-60. 
7. Halse A, Molven O, Fristad I. Diagnosing periapical lesions--disagreement and borderline cases. Int Endod J. 2002 Aug;35(8):703-9. [Medline: 12196224] [doi: 10.1046/j.1365-2591.2002.00552.x]

8. Shoha RR, Dowson J, Richards AG. Radiographic interpretation of experimentally produced bony lesions. Oral Surg Oral Med Oral Pathol. 1974 Aug;38(2):294-303. [Medline: 4528700] [doi: 10.1016/0030-4220(74)90071-1]

9. Gao Y, Haapasalo M, Shen Y, Wu H, Jiang H, Zhou X. Development of virtual simulation platform for investigation of the radiographic features of periapical bone lesion. J Endod. 2010 Aug;36(8):1404-9. Epub 2010 Jun 25. [Medline: 20647106] [doi: 10.1016/j.joen.2010.04.003]

10. de Paula-Silva FW, Wu MK, Leonardo MR, da Silva LA, Wesselink PR. Accuracy of periapical radiography and conebeam computed tomography scans in diagnosing apical periodontitis using histopathological findings as a gold standard. J Endod. 2009 Jul;35(7):1009-12. [Medline: 19567324] [doi: 10.1016/j.joen.2009.04.006]

11. Liang YH, Li G, Wesselink PR, Wu MK. Endodontic outcome predictors identified with periapical radiographs and cone-beam computed tomography scans. J Endod. 2011 Mar;37(3):326-31. [Medline: 21329816] [doi: 10.1016/j.joen.2010.11.032]

12. Velvart P, Hecker H, Tillinger G. Detection of the apical lesion and the mandibular canal in conventional radiography and computed tomography. Oral Surg Oral Med Oral Pathol Oral Radiol Endod. 2001 Dec;92(6):682-8. [Medline: 11740486] [doi: $10.1067 / \mathrm{moe} .2001 .118904]$

13. Patel S. New dimensions in endodontic imaging: Part 2. Cone beam computed tomography. Int Endod J. 2009 Jun;42(6):463-75. Epub 2009 Mar 2. Review. [Medline: 19298576] [doi: 10.1111/j.1365-2591.2008.01531.x]

14. Mozzo P, Procacci C, Tacconi A, Martini PT, Andreis IA. A new volumetric CT machine for dental imaging based on the cone-beam technique: preliminary results. Eur Radiol. 1998;8(9):1558-64. [Medline: 9866761] [doi: $10.1007 / \mathrm{s} 003300050586$ ]

15. Arai Y, Tammisalo E, Iwai K, Hashimoto K, Shinoda K. Development of a compact computed tomographic apparatus for dental use. Dentomaxillofac Radiol. 1999 Jul;28(4):245-8. [Medline: 10455389] [doi: 10.1038/sj.dmfr.4600448]

16. Abella F, Patel S, Durán-Sindreu F, Mercadé M, Bueno R, Roig M. An evaluation of the periapical status of teeth with necrotic pulps using periapical radiography and cone-beam computed tomography. Int Endod J. 2014 Apr;47(4):387-96. Epub 2013 Jul 26. [Medline: 23889592] [doi: 10.1111/iej.12159]

17. Durack C, Patel S, Davies J, Wilson R, Mannocci F. Diagnostic accuracy of small volume cone beam computed tomography and intraoral periapical radiography for the detection of simulated external inflammatory root resorption. Int Endod J. 2011 Feb;44(2):136-47. Epub 2010 Nov 17. [Medline: 21083575] [doi: 10.1111/j.1365-2591.2010.01819.x]

18. Liang YH, Li G, Shemesh H, Wesselink PR, Wu MK. The association between complete absence of post-treatment periapical lesion and quality of root canal filling. Clin Oral Investig. 2012 Dec;16(6):1619-26. Epub 2012 Jan 10. [Medline: 22228024] [PMC free article: 3501171] [doi: 10.1007/s00784-011-0671-3]

19. Cheung GS, Wei WL, McGrath C. Agreement between periapical radiographs and cone-beam computed tomography for assessment of periapical status of root filled molar teeth. Int Endod J. 2013 Oct;46(10):889-95. Epub 2013 Feb 26. [Medline: 23442122] [doi: 10.1111/iej.12076]

20. Bornstein MM, Lauber R, Sendi P, von Arx T. Comparison of periapical radiography and limited cone-beam computed tomography in mandibular molars for analysis of anatomical landmarks before apical surgery. J Endod. 2011 Feb;37(2):1517. [Medline: 21238794] [doi: 10.1016/j.joen.2010.11.014]

21. Bornstein MM, Wasmer J, Sendi P, Janner SF, Buser D, von Arx T. Characteristics and dimensions of the Schneiderian membrane and apical bone in maxillary molars referred for apical surgery: a comparative radiographic analysis using limited cone beam computed tomography. J Endod. 2012 Jan;38(1):51-7. Epub 2011 Nov 17. [Medline: 22152620] [doi: 10.1016/j.joen.2011.09.023]

22. Altman DG. Practical Statistics for Medical Research. Chapman \& Hall/CRC, London, 1991.

23. Kullendorff B, Nilsson M, Rohlin M. Diagnostic accuracy of direct Digital dental radiography for the detection of periapical bone lesions: overall comparison between conventional and direct digital radiography. Oral Surg Oral Med Oral Pathol Oral Radiol Endod. 1996 Sep;82(3):344-50. [Medline: 8884837] [doi: 10.1016/S1079-2104(96)80364-7]

24. Barbat J, Messer HH. Detectability of artificial periapical lesions using direct digital and conventional radiography. J Endod. 1998 Dec;24(12):837-42. [Medline: 10023266] [doi: 10.1016/S0099-2399(98)80014-9]

25. Low KM, Dula K, Bürgin W, von Arx T. Comparison of periapical radiography and limited cone-beam tomography in posterior maxillary teeth referred for apical surgery. J Endod. 2008 May;34(5):557-62. [Medline: 18436034] [doi: 10.1016/j.joen.2008.02.022]

26. Soğur E, Gröndahl HG, Baksı BG, Mert A. Does a combination of two radiographs increase accuracy in detecting acidinduced periapical lesions and does it approach the accuracy of cone-beam computed tomography scanning? J Endod. 2012 Feb;38(2):131-6. Epub 2011 Dec 6. [Medline: 22244624] [doi: 10.1016/j.joen.2011.10.013]

27. Petersson A, Axelsson S, Davidson T, Frisk F, Hakeberg M, Kvist T, Norlund A, Mejàre I, Portenier I, Sandberg H, Tranaeus S, Bergenholtz G. Radiological diagnosis of periapical bone tissue lesions in endodontics: a systematic review. Int Endod J. 2012 Sep;45(9):783-801. Epub 2012 Mar 19. Review. [Medline: 22429152] [doi: $10.1111 / \mathrm{j} .1365-2591.2012 .02034 . \mathrm{x}]$

28. Ng YL, Mann V, Gulabivala K. Outcome of secondary root canal treatment: a systematic review of the literature. Int Endod J. 2008 Dec;41(12):1026-46. Review. [Medline: 19133093] [doi: 10.1111/j.1365-2591.2008.01484.x] 
29. Huumonen S, Kvist T, Gröndahl K, Molander A. Diagnostic value of computed tomography in re treatment of root fillings in maxillary molars. Int Endod J. 2006 Oct;39(10):827-33. [Medline: 16948669] [doi: 10.1111/j.1365-2591.2006.01157.x]

30. Moura MS, Guedes OA, De Alencar AH, Azevedo BC, Estrela C. Influence of length of root canal obturation on apical periodontitis detected by periapical radiography and cone beam computed tomography. J Endod. 2009 Jun;35(6):805-9. [Medline: 19482175] [doi: 10.1016/j.joen.2009.03.013]

31. Liang YH, Jiang L, Gao XJ, Shemesh H, Wesselink PR, Wu MK. Detection and measurement of artificial periapical lesions by cone-beam computed tomography. Int Endod J. 2014 Apr;47(4):332-8. Epub 2013 Jul 2.[Medline: 23815501] [doi: 10.1111/iej.12148]

32. Özer SY. Detection of vertical root fractures by using cone beam computed tomography with variable voxel sizes in an in vitro model. J Endod. 2011 Jan;37(1):75-9. Epub 2010 Nov 5. [Medline: 21146082] [doi: 10.1016/j.joen.2010.04.021]

33. de Paula-Silva FW, Wu MK, Leonardo MR, da Silva LA, Wesselink PR. Accuracy of periapical radiography and conebeam computed tomography scans in diagnosing apical periodontitis using histopathological findings as a gold standard. J Endod. 2009 Jul;35(7):1009-12. [Medline: 19567324] [doi: 10.1016/j.joen.2009.04.006]

34. Varshosaz M, Tavakoli MA, Mostafavi M, Baghban AA. Comparison of conventional radiography with cone beam computed tomography for detection of vertical root fractures: an in vitro study. J Oral Sci. 2010 Dec;52(4):593-7. [Medline: 21206162] [doi: 10.2334/josnusd.52.593]

35. Venskutonis T, Juodzbalys G, Nackaerts O, Mickeviciene L. Influence of voxel size on the diagnostic ability of cone-beam computed tomography to evaluate simulated root perforations. Oral Radiol 2013;2:151-9. [doi: 10.1007/s11282-013-0125-5]

36. Bernardes RA, de Paulo RS, Pereira LO, Duarte MA, Ordinola-Zapata R, de Azevedo JR. Comparative study of cone beam computed tomography and intraoral periapical radiographs in diagnosis of lingual-simulated external root resorptions. Dent Traumatol. 2012 Aug;28(4):268-72. Epub 2012 Jan 11. [Medline: 22233265] [doi: 10.1111/j.1600-9657.2011.01113.x]

37. Qu XM, Li G, Ludlow JB, Zhang ZY, Ma XC. Effective radiation dose of ProMax 3D cone-beam computerized tomography scanner with different dental protocols. Oral Surg Oral Med Oral Pathol Oral Radiol Endod. 2010 Dec;110(6):770-6. Epub 2010 Oct 16. [Medline: 20952220] [doi: 10.1016/j.tripleo.2010.06.013]

38. Hedesiu M, Baciut M, Baciut G, Nackaerts O, Jacobs R; SEDENTEXCT Consortium. Comparison of cone beam CT device and field of view for the detection of simulated periapical bone lesions. Dentomaxillofac Radiol. 2012 Oct;41(7):548-52. Epub 2012 May 3. [Medline: 22554990] [PMC free article: 3608374] [doi: 10.1259/dmfr/19322177]

39. Shoha RR, Dowson J, Richards AG. Radiographic interpretation of experimentally produced bony lesions. Oral Surg Oral Med Oral Pathol. 1974 Aug;38(2):294-303. [Medline: 4528700] [doi: 10.1016/0030-4220(74)90071-1]

40. Brynolf I. Roentgenologic periapical diagnosis. II. One, two or more roentgenograms? Sven Tandlak Tidskr. 1970 May;63(5):345-50. [Medline: 5269173]

\section{To cite this article:}

Venskutonis T, Daugela P, Strazdas M, Juodzbalys G. Accuracy of Digital Radiography and Cone Beam Computed Tomography on Periapical Radiolucency Detection in Endodontically Treated Teeth.

J Oral Maxillofac Res 2014;5(2):e1

URL: http://www.ejomr.org/JOMR/archives/2014/2/e1/v5n2e1ht.pdf

doi: 10.5037/jomr.2014.5201

Copyright (C) Venskutonis T, Daugela P, Strazdas M, Juodzbalys G. Published in the JOURNAL OF ORAL \& MAXILLOFACIAL RESEARCH (http://www.ejomr.org), 1 July 2014.

This is an open-access article, first published in the JOURNAL OF ORAL \& MAXILLOFACIAL RESEARCH, distributed under the terms of the Creative Commons Attribution-Noncommercial-No Derivative Works 3.0 Unported License, which permits unrestricted non-commercial use, distribution, and reproduction in any medium, provided the original work and is properly cited. The copyright, license information and link to the original publication on (http://www.ejomr.org) must be included. 